\title{
Influence of Critical Thinking on the Formation of Me-Concept of a Future Officer
}

\section{Вплив критичного мислення на становлення «Я-концепції» майбутнього офіцера}

\author{
Olha Bohush \\ Ph.D. in Psychology, Officer \\ of Moral and Psychological \\ Support Department \\ Ольга Богуш \\ кандидат психологічних \\ наук, офіцер відділу \\ морально-психологічного \\ забезпечення \\ E-mail: zarowka@ukr.net \\ orcid.org/0000-0001-6747-4268 \\ Researcher ID: X-4511-2018 \\ Military Academy (Odessa), \\ Військова акаделія \\ Odessa, Ukraine \\ ( м. Одеса), м. Одеса, Украӥна \\ 10, Fontanska Road str., \\ Odessa, 65009 \\ вул. Фонтанська дорога, 10, \\ м. Одеса, 65009 \\ Original manuscript received December 18, 2018 \\ Revised manuscript accepted January 22, 2019
}

\section{ABSTRACT}

The features of critical thinking of a future officer, its structure and characteristics are analyzed in the article. It is revealed that the development of a cadet's critical thinking in the learning process is due to the development of his creative personality, which provides for the ability to statement of a problematic point and search for non-standard ways to solve them, taking into account opposing points of view and a tolerant attitude towards the opponent. The psychological factors influencing on cadets' critical thinking formation during study in higher military institutions are defined, in particular: need-motivational (the need to solve a problem task, interest in this task); cognitive (lack of knowledge and experience), personality-based (self-esteem, self-confidence level, level of aspirations, communicative potential); situatio- 
nal (extreme situation, lack of time or resources). The stages of the functioning of critical thinking are ascertained, in particular: collision with a problem; problem solving using existing knowledge; search for a new way of action, which ends with insight - the most important moment, because a new content of the investigated question appears; argumentation of the found solution. It is established that critical thinking, as the highest level of cognitive activity contributes to the development of personality qualities of the future officer. The development of cognitive processes provides effectiveness of educational activities, which affect the formation of professional self-consciousness of the cadet. The characteristics of a future officer's professional Self-conception formation and the stages of the critical thinking formation in the main components of the structure of Me-concept of a future officer are examined. It has been revealed that a quality entry into professional activities induced the development of critical thinking, which in turn contributed to a better cognitive activity of a cadet, increased his self-esteem and affected the formation of the image of an ideal officer.

Key words: critical thinking, cognitive processes, psychological factors, self-esteem, self-improvement, self-consciousness, professional development, future officers, Me-concept, Me-image.

\section{Вступ}

Входження у професію військового відбувається саме під час навчання у військовому закладі вищої освіти, де курсанти здобувають професійні знання, опановують необхідні навички та вміння й формується готовність застосовувати їх на практиці в різних екстремальних умовах. Якість функціонування пізнавальних процесів визначає ефективність навчальної діяльності, але мотивація до навчання, здібності до опанування знань, досвід, цінності тощо свідчать про те, що визначальним у формуванні професіонала є особистість курсанта, а саме розвиток його професійної самосвідомості. Останніми роками багато досліджень присвячено розвитку критичного мислення як вищого рівня пізнавальної активності особистості, що забезпечує контроль розумової діяльності, проте недостатньо розглянуто питання психологічних чинників, що впливають на розвиток критичного мислення у військовослужбовців, і питан- 
ня впливу пізнавальних процесів на розвиток професійної самосвідомості, зокрема впливу критичного мислення на розвиток «Я-концепції» військовослужбовців.

Психологічним теоріям розвитку критичного мислення людини присвячено низку робіт (D. Kluster (2005), C. Д. Максименко (1998), R. Paul (1993), S. Slameto (2017), Ch. Templ (1998), С. О. Терно (2011), О. В. Тягло (2008), D. Halpern (2011), T. I. Хачумян (2005)), зокрема критичному мисленню військових (В. І. Конаржевська (2009), О. Г. Марченко (2007), І. Ю. Тунік (2013)), що свідчить про багатогранність і важливість цього явища.

С. Д. Максименко (Максименко, 1998) розглядає критичне мислення як уміння не піддаватись впливу інших людей, що характеризується вимогливістю до власних думок і самокритичністю, а також самостійністю, яка потребує врахування знань і досвіду інших людей, творчого підходу до вирішення проблемних ситуацій. В. І. Конаржевська й А. Є. Сіренко (Конаржевська \& Сіренко, 2017) убачають у критичному мисленні складову формування комунікативних якостей військовослужбовця. І. Ю. Тунік (І. Ю. Тунік, 2013) розглядає критичне мислення як чинник психологічної та професійної підготовки військовослужбовців і виокремлює ознаки та компоненти критичного мислення у військовослужбовців під час навчання у військових закладах вищої освіти. За С. О. Терно (Терно, 2015), розв'язання проблемних питань, що потребують творчого пошуку, і є критичним мисленням. Автор окреслює етапи та рівні розвитку критичного мислення, а також зазначає основні принципи і стратегії формування критичного мислення. Н. М. Громова (Громова, 2015) виокремлює установки на критичне мислення для студентів на етапі входження у професію.

Одним із центральних понять як у вітчизняній, так i зарубіжній психологічній науці постає «Я-концепція» особистості як відносно стабільна, усвідомлена система уявлень індивіда про себе, на основі якої будується взаємо- 
дія з іншими та ставлення до самого себе (R. Berns (1986), M. Й. Боришевський (2007), D. E. Gibson (2003), I. Кон (1984), Р. В. Каламаж (2010), Marsh, W. Herbert, Martin \& J. Andrew (2011), І. Д. Пасічник (2013), В. В. Столін (1983) та ін.).

Відсутність чіткої структури понять «самосвідомість», «Я-концепція», «Я-образ», «Я-ідеал», «самоідентичність» створює розмаїття синонімічних визначень. О. О. Бодальов і В. В. Столін (Бодальов \& Столін, 1983) визначають, що «Я-концепція» $\mathrm{i}$ «Я-образ» є продуктом самосвідомості; К. Абульханова-Славська (Абульханова-Славська, 1991) розглядає «Я-концепцію» як динамічну систему уявлень про себе та включає емоційно-ціннісне ставлення до них.

За У. Кірєєвою (Кірєєва, 2010), формування «Я-концепції» відбувається через систему установок як внутрішньої готовності особи до здійснення активності. Авторка уточнює, що у структурі «Я-концепції» когнітивна складова конкретизується в «Я-образі», емоційно-оцінна - в «Я-ставленні», а поведінкова - у «Я-вчинку», зокрема становлення «Я-образу» залежить від перебігу пізнавальних процесів.

D. Gibson (Gibson, 2003) розглядає розвиток «Я-концепції» як зміну образів і ролей особистості для наслідування впродовж усієї професійної діяльності, що тісно пов'язана з підвищенням довіри до професійної самооцінки. У своєму дослідженні автор виявив, що на початку кар'єри «Я-концепція» має позитивну тенденцію, що пов'язано 3 бажанням створити життєздатну самооцінку, на середньому етапі індивід прагне удосконалити свою самооцінку, що позначається і на самопізнанні. На пізніх етапах професійної діяльності індивід прагне підтвердити та посилити свою самореалізацію.

В. I. Осьодло (Осьодло, 2011) визначив у структурі професійної самосвідомості військовослужбовців такі показники: усвідомлення професійних цінностей, усвідомлення професійної моралі, усвідомлення себе як суб’єкта 
професійної діяльності, усвідомлення й оцінка відношень і самоставлення, усвідомлення власного професійного розвитку. Невизначеність ціннісних уявлень про професію зміщує орієнтири, і професія стає засобом досягнення цілі. В. П. Москалець (Москалець, 2014) розглядає пізнавальні процеси як складові самосвідомості людини, зокрема, мислення - процес розв' язання задач, пошук виходу з проблемних ситуацій, вирішення чи подолання проблем за допомогою інтелекту.

Мета статті - визначити вплив критичного мислення на становлення «Я-концепції» майбутніх офіцерів під час навчання у військовому закладі вищої освіти.

\section{Завдання статті}

На підставі психолого-педагогічної літератури уточнити структуру та показники критичного мислення; проаналізувати специфіку формування критичного мислення у курсантів військових закладів вищої освіти на етапі їх професіоналізації; визначити психологічні чинники, що впливають на розвиток критичного мислення курсантів; розглянути особливості формування «Я-концепції» під час навчання та визначити вплив критичного мислення на становлення «Я-концепції» майбутніх офіцерів.

\section{Методи та методики}

В основі нашого дослідження лежать методи теоретичного аналізу: структурування, класифікація, аналіз, узагальнення наукових джерел, психолого-педагогічне спостереження навчально-професійної діяльності курсантів військових закладів вищої освіти. Методологічною основою нашого дослідження став компетентнісний підхід до дослідження критичного мислення, що сприяє здатності особистості використовувати засвоєні знання, вміння та ціннісні орієнтації в професійній діяльності, а також системний підхід до дослідження особливостей формування професійної «Я-концепції» майбутніх офіцерів. Ми роз- 
глядаємо «Я-концепцію» як динамічну систему уявлень індивіда про свою роль у професійному середовищі. Особистісно-орієнтовний підхід щодо підготовки майбутніх офіцерів дає змогу забезпечити і підтримати самопізнання та самореалізацію курсанта, створити сприятливі умови для розвитку творчого потенціалу його особистості.

\section{Результати та дискусії}

Унаслідок змін, що відбуваються в державі загалом і в Збройних силах України зокрема, суттєво підвищились вимоги до військового професіонала, і мова йде не лише про вміння вправно володіти зброєю та військовою технікою, головне - особистість військовослужбовця, його готовність виконати свій державний обов'язок, наявність у нього достатньої мотивації та ідейних переконань, щоб не піддаватись на провокації і негативний інформаційно-психологічний вплив противника і виконувати поставлені завдання.

Вітчизняні концепції професійного розвитку та психології профресіоналізму (Є. О. Климов (1996), О. М. Кокун (2012), О. К. Маркова (1996), М. І. Томчук (2006), В. Д. Шадриков (1996), В. М. Ямницький (2010), В. В. Ягупов (2011) та ін.) свідчать, що характеристики особистості суттєво впливають на процес мислення i результат діяльності у ході професіоналізації особистості. За О. К. Тихомировим (Тихомиров, 1984), для розгортання будь-якої мисленнєвої діяльності необхідна актуалізація потребово-мотиваційних структур, оскільки прийняття задачі обумовлює їі вирішення та співпадіння суб'єктивної й об'єктивної шкал ціннісних характеристик. Автор розглядає критичність мислення як властивість розумової діяльності, що проявляється у свідомому контролі за інтелектуальною діяльністю, як уміння зважувати аргументи всіх сторін, висувати гіпотези та перевіряти їх. Науковець убачав у цьому процесі самостійне вміння не піддаватися впливу інших, а правильно та чітко оцінювати ситуацію, вважав, що критичність мислення є основою творчої діяльності. 
Розвиток творчої особистості офіцера є одним із головних завдань у навчальному процесі В3ВО, що забезпечується технологією розвитку саме критичного мислення, яке передбачає сукупність стратегій і прийомів, направлених на зацікавленість предметом навчання, осмислення матеріалу та сприяє розвитку творчої активності курсанта. Розвиток критичного мислення є метакогнітивним розвитком, процеси якого здійснюють свідомий внутрішній контроль за розумовою діяльністю, завдяки чому суб'єкти навчання здатні усвідомити прогалини у фактичному знанні та докласти зусиль для побудови нового знання (Терно, 2011).

Критичне мислення є вищим рівнем мислення у процесі пізнання та має змістовний та операційний блоки. Змістовний блок включає загальнометодологічні принципи (необхідність самокорекції методу дослідження, врахування інших точок зору тощо) та стратегії (розділення проблеми на частини; розв'язання простіших проблем, використання смислових і графічних засобів з метою представлення проблеми різними способами, аналіз засобів і цілей); операційний блок - контроль розумової діяльності та її самовдосконалення (усвідомлення проблеми, врахування аргументів і контраргументів, виокремлення суперечностей, обгрунтування й оцінювання альтернатив, узагальнення, побудова гіпотези, розробка висновків) (Терно, 2015).

Складність і необхідність вирішення задач, які постають перед курсантом у навчальній діяльності, залежить від індивідуальної значущості задачі, що сприяє актуалізації стійких мотивів курсанта, тобто якщо у вирішенні певної задачі вбачається отримання досвіду або конкретної навички для подальшої служби, то актуалізується мотив стати військовим професіоналом. Здатність до критичного мислення в певній діяльності проявляється лише за наявності достатньої обізнаності в цьому питанні, в іншому разі особа приймає позицію опонента та погоджується з його доводами. 
Н. В. Козлова та М. С. Щеглова (Козлова \& Щеглова, 2015) виявили зв'язок між рівнем розвитку критичного мислення та психологічною безпекою у студентів закладів вищої освіти, що свідчить про те, що саме критичне мислення забезпечує глибоке осмислення результатів своєї діяльності та являється основою для побудови особистісного і професійного простору. Як виявилось під час дослідження, студентам із високим рівнем критичного мислення притаманна довіра до світу, більш позитивні переконання щодо життя та власної цінності.

Основними характеристиками критичного мислення особистості є рефлективність, самостійність, дисциплінованість, осмисленість, урахування інтересів оточуючих, самокритичність. Розвиток критичного мислення сприяє формуванню в особистості адекватної самооцінки, толерантності, умінню співпрацювати, налагоджувати комунікації, добирати й оцінювати інформацію тощо. Неготовність до критичного мислення може бути викликана як індивідуальними особливостями мислення (ригідність-стереотипність, фіксованість мислення, відсутність зацікавленості й толерантності, залежність від попереднього досвіду), так і зовнішніми причинами - недостатня інформованість, відсутність спеціальних знань і досвіду (Громова, 2015).

M. Azizi, Z. Sedaghat, A. Direkvand-Moghadam (Azizi, Sedaghat \& Direkvand-Moghadam, 2018) дослідили та підтвердили вплив критичного мислення на здатність до розв'язання проблемних питань, а також на підвищення самооцінки студентів.

О. Г. Марченко (Марченко, 2007) розглядає критичне мислення як оцінну розумову діяльність особистості, що спрямована на забезпечення професійної компетентності майбутнього фахівця, адекватної самооцінки, сталої критичної позиції в соціумі. Автор також визначає критерії сформованості критичного мислення курсантів ВЗВО: гностичний, навчально-процесуальний, особистісно-позиційний. 
В. I. Конаржевська (Конаржевська, 2009) показниками сформованості критичного мислення курсантів визначає мотивацію професійної підготовки, сформованість знань про суть і методи критичного мислення та ціннісне ставлення до нього, і такі особистісні якості, як активність, ініціативність, самостійність, об’єктивність тощо. Автор виокремлює соціально-особистісну функцію критичного мислення, що передбачає можливість реалізації громадянських і духовних цінностей та цілей військовослужбовця як захисника своєї країни. Науковець підсилює значення критичного мислення для військовослужбовців особливістю професійної діяльності, зокрема чіткою ієрархією та беззаперечною підпорядкованістю наказам старших командирів і співвідношенням наказів зі своїми власними моральними переконаннями та цінностями.

За С. О. Терно (Терно, 2011), критичне мислення - це мислення усвідомлене, самостійне, рефлексивне, цілеспрямоване, обгрунтоване, контрольоване та самоорганізоване. Функціонування критичного мислення проходить чотири послідовні етапи на підпорядкованих ієрархічних рівнях: операційному, предметному, рефлексивному, особистісному та комунікативному. Спочатку відбувається зіткнення з проблемою, що потребує рефлексії наявних знань, потім індивід намагається подолати ускладнення за допомогою наявних предметних знань (операційний і предметний рівні), що потребує вироблення нового погляду та переструктурування способу дії, що завершується осяянням (рефлексивний та особистісний рівні) й обгрунтуванням віднайденого рішення (комунікативний рівень). Найважливішим у цьому процесі є момент осяяння - з'являються ідея вирішення проблемної ситуації, новий зміст, нові властивості.

S. Slameto (Slameto, 2017) виокремлює чинники, що впливають на розвиток критичного мислення у випускників навчальних закладів, та експериментально підтверджує їх значення: навчальна програма, що містить нові складові / ситуації; готовність випускника вступити до 
професійного середовища; засвоєння попереднього матеріалу за темою; мотивація на навчання. Окрему увагу автор приділяє ролі викладача, який створює в навчальному контексті нові ситуації, креативно підходить до постановки завдань і спонукає студента до пізнавальної активності. Lisa M. Marin, Diane F. Halpern (Marin \& Halpern, 2010) провели дослідження та довели, що застосування інструкцій і настанов сприяють кращому формуванню навичок критичного мислення у підлітків.

Для нормального функціонування критичного мислення у процесі навчання С. О. Терно (Терно, 2011) виокремлює такі чинники: 1) мотивація - створення проблемної ситуації; 2) засіб навчання - розуміння правил критичного розмірковування; 3) зміст навчання - наявність проблемних задач; 4) метод навчання - створення ситуацій вибору; 5) форма навчання - забезпечення діалогу під час розв'язання задачі; 6) контроль - забезпечення рефлексії; 7) стиль навчання, що надає право на помилку та моделює ситуації з їі виправлення.

Ми вважаємо, що окреслені чинники є тими умовами, які впливають на функціонування критичного мислення задля ефективності навчання. А. В. Фурман (Фурман, 2011) розглядає чинник як наявність потреби, що задіює потенціал особистості до виконання відповідної діяльності й особистісної активності. У структурі чинника автор виокремлює джерело, що і є потребою; рушійну силу - систему внутрішніх протиріч; внутрішні умови - потенціал особистості, які спонукають до певної активності.

На нашу думку, психологічними чинниками критичного мислення курсантів військових закладів вищої освіти є: потребово-мотиваційні (необхідність вирішення проблемної задачі, інтерес до цієї задачі), когнітивні (недостатність знань, досвіду), особистісні (самооцінка, рівень упевненості в собі, рівень домагань, комунікативний потенціал), ситуаційні (екстремальна ситуація, обмеження часу, ресурсів). 
Критичне мислення використовується для розв'язання складних проблем і творчих задач, що потребують процесу пошуку (Терно, 2011). Розвиток сучасної бойової техніки вимагає від курсантів знання її технічних характеристик, розуміння її будови та можливостей. За необхідності саме вміння критично мислити і творчо підходити до вирішення задачі дасть змогу курсанту застосувати техніку в різних умовах та забезпечить її функціонування в нетипових екстремальних ситуаціях з обмеженим часом. Крім того, вміння критично мислити допоможе майбутньому офіцеру всебічно вивчати індивідуальні особливості підлеглих, вирішувати конфліктні ситуації у своєму підрозділі та виважено підходити до вирішення складних питань. Людина з несформованими навичками критичного мислення приймає імпульсивні рішення або рішення з ризиком (Тунік, 2013).

Отже, розвиток критичного мислення курсантів ВЗВО проявляється не лише в забезпеченні психологічної підготовки, але і сприяє формуванню необхідних професійних якостей військовослужбовця, що визначає готовність до виконання службових завдань.

Період старшої юності, який припадає на навчання у закладі вищої освіти, є найважливішим для розвитку професійної самосвідомості, коли відбувається усвідомлення своєї індивідуальності та неповторності, формується професійна «Я-концепція» особистості, що, в свою чергу, і зумовлює відповідну діяльність. В. В. Столін (Столін, 1983) окреслює «Я-концепцію» як важливу детермінанту діяльності людини, її поведінки в ситуаціях вибору. В «Я-концепції» містяться складові, за допомогою яких особистість відзначає в собі загальні риси і характеристики, що поєднують їі з іншими, а також виокремлює своє індивідуальне та неповторне «Я», котре вирізняє її з-поміж інших.

R. Berns (Berns, 1986) розглядає «Я-концепцію» як сукупність установок, спрямованих на самого себе, що містить у своїй цілісності три компоненти: когнітивний 

( «Я-образ») - включає характеристики індивіда, його життєві цілі, відповідні переконання, думки і знання про себе (об’єктивні та суб’єктивні); емоційно-оцінний, або афективний ( ЯЯ-ставлення») - позитивні чи негативні відчуття про себе, самооцінка, яка може змінюватись залежно від обставин та уявлень індивіда про себе через його оточення та соціальні реакції; та поведінковий ( «Я-вчинок») - готовність до відповідного способу дії задля збереження сфрормованого образу «Я», саморегуляція, самореалізація. Автор визначає три модальності самоустановок: «Я-реальне» (уявлення про себе в даний момент, свій статус, ролі, здібності), «Я-ідеальне» (уявлення про те, яким хотів би бути), «Я-дзеркальне» (уявлення про те, яким мене сприймає оточення).

«Я-концепція» сприяє досягненню внутрішньої узгодженості особистості, визначає інтерпретацію досвіду, $\epsilon$ джерелом очікувань і нерозривно існує в усіх процесах пізнання, настільки, наскільки людина може усвідомлювати себе (Berns, 1986).

Під час навчання відбувається розширення знань курсанта, формуються певні алгоритми, плани, технології: таким чином курсант опановує нові соціально-рольові схеми та змістовно розширює свій попередній досвід, відбувається рефлексія, що дає змогу курсанту усвідомити власні індивідуальність і унікальність, які виявляються в аналізі його предметної діяльності. Унаслідок цього підвищується ефективність навчальної діяльності. Водночас змінюються або доповнюються ідеали, ідеї, мотиви, виокремлюються ціннісні орієнтації, що проявляється в освітніх вчинках проведенні досліджень, вивченні додаткових матеріалів, що дає змогу підняти «Я-реальне» до «Я-ідеального» (Гуменюк, 2002).

Професійна самосвідомість формується внаслідок освоєння професійних навичок, надбання відповідних знань i супроводжується зміною поглядів, життєвих планів, ідеалів, ціннісних орієнтацій (Кірєєва, 2010). 
Ю. В. Ковальчук (Ковальчук, 2013) зазначає, що професійна «Я-концепція» формується із загальної «Я-концепції» у процесі професійного самовизначення та на етапі входження у відповідне середовище, і має ті ж самі компоненти. Автор виокремлює самореалізацію як важливу складову «Я-концепції», яка визначає формування професійного шляху людини та є критерієм позитивної професійної адаптації особистості в обраній професії.

Разом із розвитком самосвідомості в результаті опанування професійними знаннями та навичками змінюється і ставлення до самого себе, змінюються критерії для самооцінки курсанта. За результатами дослідження С. М. Калюжної та А. О. Дудко (Калюжна \& Дудко, 2016), вікові особливості, перехід з одного середовища в інше, зокрема професійне, впливають на становлення самосвідомості особистості. Так, студенти I-II курсів закладів вищої освіти, порівняно зі школярами старших класів, менш залежні від думки групи, менш активні в міжособистісних відносинах, мають вищий рівень самоповаги та самостійності, більш схильні до контролю власного життя. Це дослідження емпірично підтверджує, що вміння курсантів чітко висловлювати свої думки, аргументувати позицію впливає на формування «Я-концепції» майбутнього професіонала.

М. В. Сокольская та I. К. Коростелева (Сокольская \& Коростелева, 2018) експериментально дослідили особливості формування «Я-концепції» особистості студента у процесі навчально-професійної діяльності та виявили, що визначальними рисами особистості при формуванні «Я-концепції» Є самодостатність (самостійність) - соціабельність (залежність від групи); гіпотимія (схильність до почуття провини) - гіпотермія (самовпевненість); направленість на себе, а також сформованість професійних цінностей.

A. Pilarska and A. Suchańska (Pilarska \& Suchańska, 2015) експериментально дослідили складові (індекси) «Я-концепції» та простежили їх зв'язок із когнітивними 
процесами. Авторами визначено, що потреба в пізнанні корелює з усіма складовими досліджуваної конструкції. Виявлено кореляції індексів «Я-концепції» з особистісною ідентичністю та мисленням, хоча і не значні, проте значущі. Доведено, що зацікавленість у вирішенні проблемного питання стимулює мисленнєвий процес, органічність якого пов’ язана з єдністю всіх складових «Я-концепції» .

За результатами досліджень Р. I Сірко (Сірко, 2013), який вивчав основні структурні компоненти «Я-концепції» студентів закладів вищої освіти, виявлено, що у цій віковій групі зазначені складові розвиваються нерівномірно: найкраще сформований когнітивний компонент, а найгірше - емоційний. Відповідно автор виокремлює чинники впливу на кожний компонент «Я-концепції»: 1) когнітивний: інтелектуальні здібності, набутий соціальний досвід, успішність навчальної діяльності; 2) емоційний: тривожність, емоційна стійкість, самоконтроль; 3) поведінковий: соціальна активність, негнучкість у системі контактів, моральна нормативність.

Л. Е. Золотова (Золотова, 2015) дослідила зв’язок ціннісних конфліктів студентської молоді та структурних компонентів «Я-концепції». Емпіричним шляхом виявлено, що характеристики емоційного компонента «Я-концепції» з ціннісними конфліктами визначають негативні реакції відносно самого себе. У когнітивному компоненті вони відображаються завищеною або заниженою самооцінкою в міжособистісних відносинах, діяльності, поведінці. Ціннісні конфлікти в поведінковому компоненті «Я-концепції» пов’ язані з низькою вольовою регуляцією.

I. I. Чеснокова (Чеснокова, 1977) основними чинниками виокремлення рівнів у структурі «Я-концепції» особистості виділяє розвиток когнітивних, емоційних і вольових процесів, які забезпечують функціонування актів свідомості. Автор визначає такі критерії самосвідомості: джерела самосвідомості (діяльність або спілкування); механізми самосвідомості (самосприйняття, самоспостережен- 
ня, самоаналіз, самоосмислення); результати свідомості ( «Я-образ»). На першому рівні в структурі «Я-концепції» основним механізмом є самосприйняття та самоспостереження, на другому рівні - самоаналіз і самоосмислення, коли людина співвідносить свою поведінку, потреби, мотиви, формує життєві плани.

О. К. Тихомиров (Тихомиров, 1984) вводить поняття «Я-мислення», розуміючи при цьому процес розвитку знань про самого себе, що формують «Я-концепцію», у якій індивід є не лише суб'єктом, але й об’єктом мислення. «Я-образ» характеризується кількістю усвідомлених якостей особистості та суперечливістю знань, що входять до складу цієї конструкції.

Саме мислення є процесом формування будь-якого знання про самого себе. Підтримання узгодженості в «Я-концепції» відбувається не лише за наявності захисних механізмів, але й завдяки мисленнєвій діяльності, адже правильна оцінка своїх можливостей необхідна для того, щоб сформувати рівень домагань. Джерелом мисленнєвої діяльності є протиріччя знань про себе, що надходять від інших або формуються самостійно відповідно до певної діяльності (Тихомиров, 1984).

Здатність до критичного мислення зароджується в когнітивному компоненті «Я-концепції» особистості курсанта шляхом впливу засвоєних знань та отриманого досвіду, проте, на відміну від інших пізнавальних процесів, проблемна ситуація сприяє пошуку нових знань, виробленню нового способу виконання певних дій для вирішення поставленої задачі, що зачіпає і поведінковий компонент «Я-концепції»; пошук нового рішення проблемної ситуації супроводжується рефлексією та впливом на самооцінку емоційно-оцінний компонент; обгрунтування правильності обраного рішення та вміння вислухати думку інших поведінковий компонент «Я-концепції» особистості. Нове отримане знання позитивно впливає на самооцінку кур- 
санта, підвищує його рівень домагань, підтримує мотивацію до навчання та засвоєння нових професійних знань i навичок, впливає на комунікативні якості, що дає змогу самоствердитись у військовому колективі.

\section{Висновки}

Отже, критичне мислення виступає не лише складовою пізнавальної та розумової активності, що проявляється в усіх компонентах «Я-концепції» особистості курсанта, але і виступає психологічним чинником, який впливає на розвиток професійної «Я-концепції» майбутнього офіцера.

Перспективи подальших досліджень у цьому напрямку полягають в емпіричному виявленні особливостей розвитку критичного мислення в курсантів військових закладів вищої освіти на різних етапах навчання з урахуванням впливу психологічних чинників.

\section{Література}

Бернс Р. Развитие Я-концепции и воспитание : [пер. с англ.]. Москва, 1986. $421 \mathrm{c.}$

Боришевський М. Й. Розвиток громадянської спрямованості особистості в юнацькому віці : монографія. Київ : Педагогічна думка, 2007. $186 \mathrm{c}$.

Громова Н. М. Психологічні особливості установки на критичне мислення [Електронний ресурс]. Актуальні проблели психологї. 2015. T. 10. Вип. 27. С. 79-88. Режим доступу : http://nbuv.gov.ua/ UJRN/appsuh_2015_10_27_9.

Гуменюк О. Є. Психологія Я-концепції. Тернопіль : Економічна думка, 2002. С. 3-14.

Зотова Л. Э. Особенности Я-концепции студентов-психологов, характеризующихся внутриличностными ценностными конфликтами [Электронный ресурс]. Вестник МГОУ. Серия: Психологические науки. 2015. № 3. Режим доступа : https://DOI:10.18384/23107235-2015-3-76-84.

Каламаж Р. В. Психологія формування професійної Я-концепції майбутніх юристів : автореф. дис. ... д-ра психол. наук : 19.00.07. Київ, 2010. 50 с.

Калюжна Є. М., Дудко А. О. Психологічні особливості формування Я-концепції у старшому шкільному віці [Електронний ресурс]. Актуальні проблели педагогіки, психологї та професійної осві- 
mu. 2016. № 1. Режим доступу : http://journals.uran.ua/apppfo/ article/view/59868.

Кірєєва У. Психологічний аналіз Я-концепції у контексті самосвідомості [Електронний ресурс]. Психологія і суспільство. 2010. № 36. C. 120-130. Режим доступу : http://pis.tneu.edu.ua/index.php/ pis/article/view/456.

Климов Е. А. Психология профессионала. Москва : Изд-во «Институт практической психологии»; Воронеж : НПО «МОДЭК», 1996. $400 \mathrm{c}$.

Клустер Д. Что такое критическое мышление? Критическое мышление и новые виды гралотности. Москва : ЦГЛ, 2005.

Ковальчук Ю. В. Психологічні основи дослідження професійної Я-концепції особистості офіцера оперативно-розшукового підрозділу ДПС України [Електронний ресурс]. Зб. наук. праць НАДПСУ.Сер.: Педагогічні та психологічні науки. 2013. № 3. С. 301-312. Режим доступу : http://nbuv.gov.ua/UJRN/znpnapv_ppn_2013_3_33.

Козлова Н. В., Щеглова М. С. Взаимосвязь уровня критического мышления и психологической безопасности студентов высшей школы [Электронный ресурс]. Сибирский психологический журнал. 2015. № 57. C. 34-49. Режим доступа : DOI:10.17223/17267080/57/3.

Кокун О. М. Психологія професійного становлення сучасного фахівця : монографія. Київ : ДП «Інформ.-аналіт. агентство», 2012. 200 с.

Кон И. С. В поисках себя: Личность и ее самосознание. Москва : Политиздат, 1984. 335 с.

Конаржевська В. І., Сіренко А. Є. Критичне мислення як складова формування комунікативних якостей військового лідера [Електронний ресурс]. Зб. наук. праць «Педагогіка та психологія». Харків, 2017. Вип. 58. Режим доступу : https://doi.org/10.5281/ zenodo.1117001.

Конаржевська В. І. Формування критичного мислення майбутніх офіцерів у процесі професійної підготовки : автореф. дис. ... канд. пед. наук : 13.00.04. Харків, 2009. 23 с.

Максименко С. Д. Основи генетичної психології : навч. посіб. Київ : НПЦ «Перспектива», 1998. 220 с.

Маркова А. К. Психология профессионализма. Москва : Знание, 1996. $308 \mathrm{c}$.

Москалець В. Сутність інтелекту, мислення, мовлення, свідомості як психофункціональних данностей [Електронний ресурс]. Психологія і суспільство. 2014. № 4. С. 114-131. Режим доступу : http:// nbuv.gov.ua/UJRN/Psis_2014_4_11.

Осьодло В. І. Розвиток Я-образу офіцера на різних етапах професійного становлення [Електронний ресурс]. Вісник НАДПСУ. Психологічні науки. 2011. Вип. 5. Режим доступу : https://scholar. 

google.com.ua/scholar?cluster $=9342936464153392747 \& \mathrm{hl}=\mathrm{uk} \&$ as_sdt $=0,5 \& \operatorname{sciodt}=0,5$.

Пасічник І. Д. Мислення як предмет психології. Наукові записки. Сeрія: Психологія $і$ педагогіка. Острог : Національний університет «Острозька академія», 2013. Вип. 25. С. 3-9.

Сірко Р. I. Структура «Я-концепції» студентів-психологів вищих навчальних закладів Державної служби України з надзвичайних ситуацій [Електронний ресурс]. Науковий вісник ЛДУВС. Серія: Психологічна. 2013. Вип. 2. С. 158-166. Режим доступу : http:// nbuv.gov.ua/UJRN/Nvldu_2013_2_18.

Сокольская М. В., Коростелева И. К. Формирование Я-концепции личности профессионала в процессе учебно-профессиональной деятельности [Электронный ресурс]. Вестник Келеровского государственного университета. 2018. № 3. С. 121-128. Режим доступа : https://doi.org/10.21603/2078-8975-2018-3-121-128.

Столин В. В. Самосознание личности. Москва : МГУ, 1983. 286 с.

Темпл Ч., Стіл Дж., Мередіт К. Розвиток критичного мислення у навчанні різних предметів: методична система. Київ : НМЦ розвитку критичного та образного мислення «Інтелект», 1998. 32 с.

Терно С. О. Критичне мислення: стратегії та процедури [Електронний ресурс]. Наукові праці історичного факультету Запорізького національного університету. 2015. Вип. 44, Т. 2. Режим доступу : http://sites.znu.edu.ua/interactiv.edu.lab/Statti_z2012/TernoCT-stretegies.pdf.

Терно С. О. Освітня практика критичного мислення [Електронний ресурс]. Постлетодика. 2013. № 6. С. 3-8. Режим доступу : http:// nbuv.gov.ua/UJRN/Postmetodyka_2013_6_4.

Терно С. О. Теорія розвитку критичного мислення - сучасна методологічна основа історичної освіти [Електронний ресурс]. Режим доступу : http://virtkafedra.ucoz.ua/el_gurnal/pages/vyp7/konf1/ Terno.pdf.

Тихомиров О. К. Психология мышления : учеб. пособие. Москва : МГУ, 1984. $272 \mathrm{c}$.

Томчук М. І., Овчаренко Ю. О. Психологічні особливості професійної самосвідомості військовослужбовців : монографія. Одеса : ОРІДУ НАДУ, 2006. 194 с.

Тунік І. Ю. Психологічне сприяння розвитку критичного мислення в освітньому процесі у вищих військових навчальних закладах [Електронний ресурс]. Наукові праці МАУП. Сер.: Еконолічні науки. Психологічні науки. 2013. Вип. 2. С. 139-144. Режим доступу : http://nbuv.gov.ua/UJRN/Npmaupe_2013_2_27.

Тягло О. В. Критичне мислення : навч. посібник. Харків : Основа, 2008. $192 \mathrm{c}$. 
Фурман А. В., Ковальова Т. Є. Категоріальна матриця взаємозв'язку образів об`єктивної реальності і психологічних чинників самоактуалізації дорослого. Психологія і суспільство. 2011. № 4. С.42-54.

Хачумян Т. І. Формування критичного мислення студентів вищих навчальних закладів засобами інформаційних технологій : дис. ... канд. пед. наук : 13.00.09. Харків, 2005. 20 с.

Чеснокова И. И. Проблема самосознания в психологии. Москва : Наука, 1977. $144 \mathrm{c}$.

Шадриков В. Д. Психология деятельности и способности человека : учеб. пособие для вузов. 2-е изд., перераб. и доп. Москва : Логос, $1996.320 \mathrm{c.}$

Ягупов В. В. Компетентнісний підхід до професійної підготовки майбутніх фахівців у системі професійно-технічної освіти. Наук.-метод. журнал Креативна педагогіка. Акаделія міжнародного співробітництва з креативної педагогіки. Вінниця, 2011. Вип. 4. С. 28-35.

Ямницький В. М. Професійний розвиток особистості в контексті психології життєтворчості. Освіта регіону. 2010. № 1. С. 94-96.

Azizi, M., Sedaghat, Z., \& Direkvand-Moghadam, A. (2018). Effect of Critical Thinking Education on Problem Solving Skills and Self-Esteem in Iranian Female Students. Journal of Clinical \& Diagnostic Research, 12, Issue 1, 4-7. Retrieved from https://doi:10.7860/ JCDR/2018/27993.11128.

Gibson, D. E. (2003). Developing the Professional Self-Concept: Role Model Construals in Early, Middle, and Late Career Stages. Organization Science Published Online. Retrieved from https://doi.org/10.1287/ orsc.14.5.591.16767.

Marsh, Herbert, W., Martin, \& Andrew, J. (2011). Academic self-concept and academic achievement: Relations and causal ordering. British Journal of Educational Psychology, 81 (1), 59-77. Retrieved from https://doi:10.1348/000709910X503501.

Marin, L. M., \& Halpern, D. F. (2011). Pedagogy for developing critical thinking in adolescents: Explicit instruction produces greatest gains. Thinking Skills and Creativity, 6, Issue 1, 1-13. Retrieved from https://doi.org/10.1016/j.tsc.2010.08.002.

Pilarska, A., \& Suchańska, A. (2015). Self-Complexity and Self-Concept Differentiation - What Have We Been Measuring for the Past 30 Years? Current Psychology (New Brunswick, N. j.), 34, Issue 4, 723743. Retrieved from https://doi:[10.1007/s12144-014-9285-7].

Paul, R. W. (1993). Critical Thinking: What Every Person Needs to Survive. A Rapidly Changing World. 38rd edition revisited. Santa Rosa, CA, pp. 97-98.

Slameto, S. (2017). Critical thinking and its affecting factors. Jurnal Penelitian Humaniora, 18, № 2, 1-11. Retrieved from https://doi: 10.23917/humaniora.v18i2.5187. 


\section{References}

Berns, R. (1986). Razvitie Ja-koncepcii i vospitanie [The development of self-concept and education]. Moskva [in Russian].

Boryshevskyi, M. Y. (2007). Rozvytok hromadianskoi spriamovanosti osobystosti $v$ yunatskomu vitsi [Development of civic orientation of the person in the youth vice]. Kyiv: Pedahohichna dumka [in Ukrainian].

Hromova, N. M. (2015). Psykholohichni osoblyvosti ustanovky na krytychne myslennia [Psychological features of the installation on critical thinking]. Aktualni problemy psykholohii - Actual problems of psychology, 27, 79-88. Retrieved from http://nbuv.gov.ua/UJRN/ appsuh_2015_10_27_9[in Ukrainian].

Humeniuk, O. Ye. (2002). Psykholohiia Ya-kontseptsii [Psychology of I-concepts]. Ternopil : Ekonomichna dumka [in Ukrainian].

Zotova, L. Je. (2015). Osobennosti Ja-koncepcii studentov-psihologov, charakterizujushchichsja vnutrilichnostnymi cennostnymi konfliktami [Specificities of Self-conception of students-psychologists having intrapersonal conflicts of values]. Vestnik MGOU - Bulletin of Moscow State University. Series: Psychological Sciences, 3. Retrieved from https://DOI:10.18384/2310-7235-2015-3-76-84 [in Russian].

Kalamazh, R. V. (2010). Psykholohiia formuvannia profesiinoi Ya-kontseptsii maibutnikh yurystiv [Psychology of the formation of a professional I-concept of future lawyers]. Extended abstract of candidate's thesis. Kyiv : IP name G. S. Kostiuk NAPU [in Ukrainian].

Kaliuzhna, Ye. M., \& Dudko, A. O. (2016). Psykholohichni osoblyvosti formuvannia Ya-kontseptsii u starshomu shkilnomu vitsi [Psychological features of formation of self-consept in the senior school age]. Aktualni problemy pedahohiky, psykholohii ta profesiinoi osvity - Actual problems of pedagogy, psychology and vocational education, 1 . Retrieved from http://journals.uran.ua/apppfo/article/view/59868 [in Ukrainian].

Kirieieva, U. (2010). Psykholohichnyi analiz Ya-kontseptsii u konteksti samosvidomosti [Psychological Analysis of I-Concept in the Concept of Selfconsciousness]. Psykholohiia i suspilstvo - Psychology and society, 36, 120-130. Retrieved from http://pis.tneu.edu.ua/index. $\mathrm{php} / \mathrm{pis} /$ article/view/456 [in Ukrainian].

Klimov, E. A. (1996). Psihologija professionala [Psychology of a professional]. Moskva : Izd-vo «Institut prakticheskoj psihologii» ; Voronezh : NPO «MODJeK» [in Russian].

Kluster, D. (2005). Chto takoe kriticheskoe myshlenie? [What is critical thinking?]. Kriticheskoe myshlenie i novye vidy gramotnosti-Critical thinking and new forms of literacy. Moskva: CGL [in Russian].

Kovalchuk, Yu. V. (2013). Psykholohichni osnovy doslidzhennia profesiinoi Ya-kontseptsii osobystosti ofitsera operatyvno-rozshukovoho pidroz- 
dilu DPS Ukrainy [Psychological principles of professional selfconcept of personality of officer of operational and investigational unit of the State Border Guard Service of Ukraine]. Pedahohichni ta psykholohichni nauky - Psychological and pedagogical sciences: Collection of scientific article, 3, 301-312. Retrieved from http:// nbuv.gov.ua/UJRN/znpnapv_ppn_2013_3_33 [in Ukrainian].

Kozlova, N. V., \& Shcheglova, M. S. (2015). Vzaimosvjaz' urovnja kriticheskogo myshlenija i psihologicheskoj bezopasnosti studentov vysshej shkoly [The intercorrelation of critical thinking and psychological health of higher education students]. Sibirskij psihologicheskij zhurnal - Siberian Psychological Journal, 57, 34-49. Retrieved from https://DOI:10.17223/17267080/57/3 [in Russian].

Kokun, O. M. (2012). Psykholohiia profesiinoho stanovlennia suchasnoho fakhivtsia [Psychology of professional formation of a modern specialist]. Kyiv : DP «Inform.-analit. ahentstvo» [in Ukrainian].

Kon, I. S. (1984). V poiskah sebja: Lichnost' i eje samosoznanie [In search of yourself: Personality and self-awareness]. Moskva : Politizdat [in Russian].

Konarzhevska, V. I., \& Sirenko, A. Ye. (2017). Krytychne myslennia yak skladova formuvannia komunikativnykh yakostei viiskovoho lidera [Critical thinking as an integral part of formation of military leader's communicative qualities]. Pedahohika ta psykholohiia - Pedagogy and psychology: Collection of scientific article, 58. Retrieved from https://doi.org/10.5281/zenodo.1117001 [in Ukrainian].

Konarzhevska, V. I. (2009). Formuvannia krytychnoho myslennia maibutnikh ofitseriv $u$ protsesi profesiinoi pidhotovky [Formation of critical thinking of future officers in the process of training]. Extended abstract of candidate's thesis. Kharkiv : KhNPU [in Ukrainian].

Maksymenko, S. D. (1998). Osnovy henetychnoi psykholohii [Fundamentals of Genetic Psychology]. Kyiv : NPTs «Perspektyva» [in Ukrainian].

Markova, A. K. (1996). Psihologija professionalizma [Psychology of professionalism]. Moskva : Znanie [in Russian].

Moskalets, V. P. (2014). Sutnist intelektu, myslennia, movlennia, svidomosti yak psykhofunktsionalnykh dannostei [Essence of Intelligence, Thinking, Speaking, Consciousness as Psychofunctional Realias]. Psykholohiia i suspilstvo - Psychology and society, 4, 114-131. Retrieved from http://nbuv.gov.ua/UJRN/Psis_2014_4_11 [in Ukrainian].

Osiodlo, V. I. (2011). Rozvytok Ya-obrazu ofitsera na riznykh etapakh profesiinoho stanovlennia [Development of the I-image of an officer at various stages of professional development]. Visnyk NADPSU. Psykholohichni nauky - Scientific bulletin NADPSU. Psychological sciences, 5. Retrieved from https://scholar.google.com.ua/scholar?c 
luster $=9342936464153392747 \& \mathrm{hl}=\mathrm{uk} \&$ as_sdt $=0,5 \& \operatorname{sciod} t=0,5[$ in Ukrainian].

Pasichnyk, I. D. (2013). Myslennia yak predmet psykholohii [Thinking as a subject of psychology proceedings]. Naukovi zapusky. Seriia: Psykholohiia i pedahohika - Series: Psychology and Pedagogy, 25. Ostrog : Natsinalnyi universytet «Ostrozka akademiia» [in Ukrainian].

Sirko, R. I. (2013). Struktura «Ja-kontseptsii» studentiv-psykholohiv vyshchykh navchalnykh zakladiv Derzhavnoi sluzhby Ukrainy z nadzvychainykh sytuatsii [A structure of the «I-concept» in the personality of students-psychologists in the higher educational establishments of Civil Service of Emergencies of Ukraine]. Naukovyi visnyk LDUVS. Seriia psykholohichna - Psychological serial of Scientific bulletin LDUVS, 2, 158-166. Retrieved from http://nbuv.gov.ua/ UJRN/Nvldu_2013_2_18[in Ukrainian].

Sokol'skaja, M. V., \& Korosteleva, I. K. (2018). Formirovanie Ja-koncepcii lichnosti professionala $\mathrm{v}$ processe uchebno-professional'noi dejatel'nosti [I-concept of one's Professional Identity: Formation in Class and at Work]. Vestnik Kemerovskogo gosudarstvennogo universiteta - Bulletin of Kemerovo State University, 3, 121-128. Retrieved from https://doi.org/10.21603/2078- 8975-2018-3-121-128 [in Russian].

Stolin, V. V. (1983). Samosoznanie lichnosti [Self-consciousness of the person]. Moskva : MGU [in Russian].

Templ, Ch., Stil, Dzh., \& Meredit, K. (1998). Rozvytok krytychnoho myslennia u navchanni riznykh predmetiv: metodychna systema [Development of critical thinking in the study of various subjects ]: methodical system. Kyiv : NMTs rozvytku krytychnoho ta obraznoho myslennia «Intelekt» [in Ukrainian].

Terno, S. O. (2015). Krytychne myslennia: stratehii ta protsedury [Critical Thinking: Strategies and Procedures]. Naukovi pratsi istorychnoho fakultetu Zaporizkoho natsionalnoho universytetu-Scientific works of the historical faculty of Zaporizhzhya National University, 2, Issue 44. Retrieved from http://sites.znu.edu.ua/interactiv.edu.lab/ Statti_z2012/Terno-CT-stretegies.pdf [in Ukrainian].

Terno, S. O. (2013). Osvitnia praktyka krytychnoho myslennia [Critical Thinking educational practice]. Postmetodyka-Postmethodics, 6, 3-8. Retrieved from http://nbuv.gov.ua/UJRN/Postmetodyka_6_4 [in Ukrainian].

Terno, S. O. (2011). Teoriia rozvytku krytychnoho myslennia - suchasna metodolohichna osnova istorychnoi osvity [The theory of development of critical thinking is a modern methodological basis of historical education]. Retrieved from http://virtkafedra.ucoz.ua/el_gurnal/pages/vyp7/konf1/Terno.pdf [in Ukrainian]. 
Tihomirov, O. K. (1984). Psihologija myshlenija [Psychology of thinking]. Moskva : MGU [in Russian].

Tomchuk, M. I., \& Ovcharenko, Yu. O. (2006). Psykholohichni osoblyvosti profesiinoi samosvidomosti viiskovosluzhbovtsiv [Psychological peculiarities of professional self-consciousness of servicemen]. Odesa : ORIDU NADU [in Ukrainian].

Tunik, I. Yu. (2013). Psykholohichne spryiannia rozvytku krytychnoho myslennia $\mathrm{v}$ osvitnomu protsesi u vyshchykh viiskovykh navchalnykh zakladakh [Psychological assistance in the development of critical thinking in the educational process in higher military educational institutions]. Naukovi pratsi MAUP.Ser.: Ekonomichni nauky. Psykholohichni nauky - Economic sciences. Psychological sciences: Scientific works of MAUP, 2, 139-144. Retrieved from http://nbuv. gov.ua/UJRN/Npmaupe_2013_2_27[in Ukrainian].

Tiahlo, O. V. (2008). Krytychne myslennia [Critical thinking]. Kharkiv : Osnova, 2008 [in Ukrainian].

Furman, A. V., \& Kovalova, T. Ye. (2011). Katehorialna matrytsia vzaiemozviazku obraziv obiektyvnoi realnosti i psykholohichnykh chynnykiv samoaktualizatsii dorosloho [Categorical matrix of interrelation of images of objective reality and psychological factors of selfactualization of an adult]. Psykholohiia $i$ suspilstvo-Psychology and society, 4, 42-54 [in Ukrainian].

Hachumian, T. I. (2005). Formuvannia krytychnoho myslennia studentiv vyshchykh navchalnykh zakladiv zasobamy informatsiinykh tekhnolohii [Formation of Critical Thinking of Students of Higher Educational Institutions by means of Information Technologies] Extended abstract of candidate's thesis. Kharkiv : KhNPU [in Ukrainian].

Chesnokova, I. I. (1977). Problema samosoznanija v psihologii [The problem of self-consciousness in psychology]. Moskva : Nauka [in Russian].

Shadrikov, V. D. (1996). Psihologija dejatel'nosti $i$ sposobnosti cheloveka [Psychology of human activity and abilities]. Moskva : Logos [in Russian].

Yahupov, V. V. (2011). Kompetentnisnyi pidkhid do profesiinoi pidhotovky maibutnikh fakhivtsiv u systemi profesiino-tekhnichnoi osvity [Competent approach to professional training of future specialists in the system of vocational education]. Nauk.-metod. zhurnal Kreatyvna pedahohika. Akademiia mizhnarodnoho spivrobitnytstva z kreatyvnoi pedahohiky - Journal of Creative Pedagogy. Academy of International Cooperation in Creative Pedagogy, 4, 28-35 [in Ukrainian].

Yamnytskyi, V. M. (2010). Profesiinyi rozvytok osobystosti v konteksti psykholohii zhyttietvorchosti [Professional development of personality in the context of psychology of life-creation]. Osvita rehionu Education of the region, 4, 94-96 [in Ukrainian]. 
Azizi, M., Sedaghat, Z., \& Direkvand-Moghadam, A. (2018). Effect of Critical Thinking Education on Problem Solving Skills and Self-Esteem in Iranian Female Students. Journal of Clinical \& Diagnostic Research, 12, Issue 1, 4-7. Retrieved from https://doi:10.7860/ JCDR/2018/27993.11128.

Gibson, D. E. (2003). Developing the Professional Self-Concept: Role Model Construals in Early, Middle, and Late Career Stages. Organization Science Published Online. Retrieved from https://doi.org/10.1287/ orsc.14.5.591.16767.

Marsh, Herbert, W., Martin, \& Andrew, J. (2011). Academic self-concept and academic achievement: Relations and causal ordering. British Journal of Educational Psychology, 81 (1), 59-77. Retrieved from https://doi:10.1348/000709910X503501.

Marin, L. M., \& Halpern, D. F. (2011). Pedagogy for developing critical thinking in adolescents: Explicit instruction produces greatest gains. Thinking Skills and Creativity, 6, Issue 1, 1-13. Retrieved from https://doi.org/10.1016/j.tsc.2010.08.002.

Pilarska, A., \& Suchańska, A. (2015). Self-Complexity and Self-Concept Differentiation - What Have We Been Measuring for the Past 30 Years? Current Psychology (New Brunswick, N. j.), 34, Issue 4, 723743. Retrieved from https://doi:[10.1007/s12144-014-9285-7].

Paul, R. W. (1993). Critical Thinking: What Every Person Needs to Survive. A Rapidly Changing World. 38rd edition revisited. Santa Rosa, CA, pp. 97-98.

Slameto, S. (2017). Critical thinking and its affecting factors. Jurnal Penelitian Humaniora, 18, № 2, 1-11. Retrieved from https://doi: 10.23917/humaniora.v18i2.5187.

\section{АНОТАЦІЯ}

У статті проаналізовано особливості критичного мислення майбутнього офіцера, його структуру та характеристики. Виявлено, що розвиток критичного мислення курсанта у процесі навчання обумовлений розвитком його творчої особистості, що передбачає здатність до постановки проблемних питань і пошуку нестандартних шляхів їх вирішення, врахування протилежних точок зору й толерантного ставлення до опонента. Визначено психологічні чинники, які впливають на формування критичного мислення у курсантів під час навчання у військовому закладі вищої освіти: потребово-мотиваційні (необхідність вирішення проблемної задачі, інтерес до цієї задачі); когнітивні (недостатність знань, досвіду); особистісні (самооцінка, рівень упевненості в собі, рівень домагань, комунікативний потенціал); ситуаційні (екстремальна ситуація, обмеження часу, ресурсів). З’ясовано етапи 
функціонування критичного мислення: зіткнення з проблемою; усунення ускладнень за допомогою наявних знань; вироблення нового способу діï, що завершується осяянням - найважливішим моментом, оскільки з'являється новий зміст порушеного питання; обгрунтування знайденого рішення. Установлено, що критичне мислення як найвищий рівень пізнавальної активності сприяє розвитку особистісних якостей майбутнього офіцера, розвиток пізнавальних процесів забезпечує ефективність навчальної діяльності, що впливає на формування професійної самосвідомості курсанта. Розглянуто особливості становлення профресійної «Я-концепції» й етапи формування критичного мислення в основних компонентах структур “Я-концепції» майбутнього офіцера. Виявлено, що якісне входження в професійну діяльність стимулює розвиток критичного мислення, що, в свою чергу, сприяє кращій пізнавальній активності курсанта, підвищує його самооцінку та впливає на формування образу ідеального офіцера в його свідомості.

Ключові слова: критичне мислення, пізнавальні процеси, психологічні чинники, самооцінка, самовдосконалення, самосвідомість, професійний розвиток, майбутні офіцери, «Я-концепція», «Я-образ».

\section{Богуш Ольга. Влияние критического мышления на становление «Я-концепции» будущего офицера}

\section{АННОТАЦИЯ}

В статье проанализированы особенности критического мышления, его структура и характеристики. Выявлено, что развитие критического мышления курсанта в процессе обучения обусловлено развитием его творческой личности, что предусматривает способность к постановке проблемных вопросов и поиску нестандартных путей их решения, с учетом противоположных точек зрения и толерантного отношения к оппоненту. Определены психологические фракторы, которые влияют на фрормирование критического мышления у курсантов в процессе обучения в высшем военном учебном заведении: потребносно-мотивационные (необходимость решения проблемной задачи, интерес к данной задаче); когнитивные (недостаточность знаний, опыта), личностные (самооценка, уровень уверенности в себе, уровень притязаний, коммуникативный потенциал); ситуационные (экстремальная ситуация, недостаточность времени, ресурсов). Определены этапы функционирования критического мышления: столкновение с проблемой; устранение сложностей с помощью имеющихся знаний; 
разработка нового способа действий, который завершается озарением - самым важным моментом, поскольку появляется новое содержание исследуемого вопроса; обоснование найденного решения. Установлено, что критическое мышление как наивысший уровень познавательной активности способствует развитию личностных качеств будущего офицера, развитие познавательных процессов обеспечивает эффрективность учебной деятельности, что влияет на формирование профрессиональной сознательности курсанта. Рассмотрены особенности становления профессиональной "Я-концепции» и этапы формирования критического мышления в основных компонентах структуры "Я-концепции» будущего офицера. Выявлено, что адекватное вхождение в профрессиональную деятельность стимулирует развитие критического мышления, что, в свою очередь, способствует лучшей познавательной активности курсанта, повышает его самооценку и влияет на формирование образа идеального офицера.

Ключевые слова: критическое мышление, познавательные процессы, психологические факторы, самооценка, самоусовершенствование, самосознание, профессиональное развитие, будущие офицеры, «Я-кониепция», «Я-образ». 